\title{
Radiation and its Isotopes uses and Drawbacks
}

\author{
Indu Thakur* \\ Radiation Biology, India \\ Submission: August 01, 2017; Published: August 21, 2017 \\ *Corresponding author: Indu Thakur, Radiation Biology, India, Email: indu123_thakur@yahoo.co.in
}

\section{Opinion}

Radiation is the propagation of radiant energy in the form of waves or particles. It may also include beams of particles of which electrons, positrons, neutrons, protons, deuterons, and are the alpha particles are the best known. When, radioactivity is defined as the property, possessed by some materials, of spontaneously emitting alpha or beta particles or gamma rays as the unstable (or radioactive) nuclei of their gamma rays as the unstable (or radioactive) nuclei of their atoms disintegrate and the Radioisotopes are isotopes that are unstable, or radioactive, and give off radiation spontaneously and may be used either as a source of radiation energy or as a tracer.

Radioisotopes offer two advantages. First, they can be used in extremely small amount. Secondly, they can, be directed to various definitely known parts of the body. For example, radioactive sodium iodide found in the iodized salt used in many homes and their iodine concentrates in the thyroid where it is converted to the hormone thyroxin.

Other radioactive or "tagged" atoms can be routed to bone marrow, red blood cells, the liver, the kidneys, or made to remain in the blood stream, where they are measured using suitable instruments. When radiation is used for treatment, the energy absorbed by the body is used either to destroy tissue, particularly cancer, or to suppress some function of the body. Properly calculated and applied doses of radiation can be used to produce the desired effect with minimum side effects. More than 100 different radioisotopes that have been used by doctors during the past so many years, five have received by far the greatest attention. These are iodine-131, phosphorous-32, gold198, chromium-51 and iron-59 whereas Radioactive sulphur $\left(\mathrm{S}^{35}\right)$ helps to study advantages and disadvantages offungicides.

Arsenic-74 and copper-64 are isotopes emitting positrons. Chromium-51 in the molecule sodium chromate, attaches itself to red blood cells, it is useful in several kind of tests. When chromium trichloride $\mathrm{CrCl}_{3}$ is used as the tagging agent, the chromium is bound almost exclusively to plasma proteins, rather than the red cells.Chrmium-51 may thus be used for estimating the volume of plasma circulating in the heart and blood vessels. This ${ }^{51} \mathrm{Cr}$ procedure was used during the Korean War to determine how much blood had been lost by wounded patients, and helped to save many many lives. Iodine-131has been used as a tracer in determining cardiac output, which is the rate of blood flow from the heart. It has appeared recently that red blood cells tagged with ${ }^{51} \mathrm{Cr}$ are more satisfactory for this measurement than iodine-labeled albumin in the blood serum.

Cobalt-60, Vitamin $\mathrm{B}^{12}$ is a cobalt compound the few milligram of $\mathrm{B}^{12}$ in the body are stored in the liver and present in the blood stream.Iodine-131, Iodine is versatile tracer element. It is used to determine blood volume, cardiac output, plasma volume, liver activity, fat metabolism, thyroid, cancer metastases, brain tumors, and the size, shape and activity of the thyroid gland. Human serum albumin labeled with 131I is sometimes used for location of brain tumors it is alternative form of "blood brain barrier".

Iron-59 is a necessary constituent of red blood cells, so its radioactive form, where ${ }^{59} \mathrm{Fe}$, has been used frequently in measurement of the rate of formation of red cells, the life-time of red cells, and the red cells volumes. Phosphorus-32, the Phosphate ion is a normal constituent of the blood. Phosphate concentration in the cancerous tissue is higher as compare with the surrounding healthy tissue and the radioactive phosphorus $\left(\mathrm{P}^{32}\right)$ is used in the study of metabolism of plants. Sodium $-24,{ }^{24} \mathrm{Na}$, use for the measurement of the blood and the other fluids. The elapsed time is a good indication of the presence or absence of constrictions or obstructions in the circulatory system. The passage of blood through the heart may also be measured with the aid of sodium- 24 .

Technetium-99m particularly used for scanning brain tumors. A stock of molybdenum is kept in a shielded container in which it undergoes radioactive decay yielding technetium. Thulium-170 and Gamma Radiography, the thulium-170 was used for X-rays pictures and the gamma rays used the source are sufficiently penetrating for photographing the arms and legs. It is safe to move an accident victim, for instance in military 
operations, similarly, it becomes a simple matter to examine wounded soldiers in the field where conventional equipment is not available. Tritium $-{ }^{3} \mathrm{H}$ has been (radioactive hydrogen) produced in abundance. Its oxide, triturated water $\left(3 \mathrm{H}_{2} \mathrm{O}\right)$, is chemically almost the same as ordinary water used for measuring blood plasma volume and total water volume availability in body.

Boron-10 has been used experimentally in the treatment of inoperable brain tumors. The maximum destruction of the cancer cell will occur, along with minimum hazard to the patient. The difficulty is that most boron compounds themselves are poisonous to human tissues, and only small concentrations can be tolerated in the blood. Gold-198 offers several advantages. It has a short half-life (2.7 days) it is chemically inert and therefore nontoxic: and it emits beta and gamma radiation that is almost entirely absorbed by the tissues and help to find out the malignancies. Pests and insects on crops can be killed by radiations and - rays are used for preservation of milk, potatoes etc. whereas Yield of crops like carrot, root, apples, and grapes can be increased by irradiation with radioisotopes.

\section{Drawbacks}

The radiations emitted by these isotopes will induce damage in the developing embryo and fetus. Internally deposited isotopes can cause more harm to the particular organ and tissue in which they are localized. Three radionuclides, tritium $\left({ }^{3} \mathrm{H}\right)$, Iodine-131 and plutonium-239, are among the most noteworthy for human exposure under normal conditions and in accidents. The damaging effect of ${ }^{3} \mathrm{H}$ and ${ }^{239} \mathrm{Pu}$ on embryos has been studied in mice and rats. Whole body doses of $1 \mathrm{~Gy}$ or less from tritium has been reported to reduce litter size, change sex ratio and increases neonatal mortality in mice. Sustained levels of tritium in drinking water of pregnant rats at concentrations of $100 \mathrm{kBq} /$ $\mathrm{ml}$ cause reduction in DNA and protein contents of fetal brain. Experimental evidence shows that for the same administered activity, the organically bound tritium (triturated thymidine) is much more harmful than tritiated water (UNSCEAR 1986). Very little information is available on the effects of other biologically relevant radionuclides on prenatal development.

\begin{tabular}{l} 
Your next submission with Juniper Publishers \\
will reach you the below assets \\
- Quality Editorial service \\
- Swift Peer Review \\
- Reprints availability \\
- E-prints Service \\
- Manuscript Podcast for convenient understanding \\
- Global attainment for your research \\
- Manuscript accessibility in different formats \\
( Pdf, E-pub, Full Text, Audio) \\
- Unceasing customer service \\
Track the below URL for one-step submission \\
https://juniperpublishers.com/online-submission.php \\
\hline
\end{tabular}

